\title{
PACTISM IN CATALONIA: A DUAL CONCEPTION OF THE POLITICAL COMMUNITY
}

\author{
Tomàs de Montagut (iD \\ (Universitat Pompeu Fabra) \\ tomas.montagut@upf.edu \\ Pere Ripoll 1 \\ (Universitat Pompeu Fabra) \\ pere.ripoll@upf.edu
}

\begin{abstract}
This article offers a historiographic definition of 'pactism', i.e. the pact-based model institutional doctrine and practice held in Europe from the High-Middle Ages onwards, until the emergence of the modern concept of sovereignty in the absolutist state of the 16th and 17th centuries. As institutional doctrine, pactism found in Catalonia one of its most elaborate formulations. This article defines the constitutive elements of Catalan legal pactism, stemming from the Romanist concept of ius commune and the conceptual work on interpretation and early public law carried out by legal scholars. It distinguishes different kinds and degrees of jurisdictio (senyoria, in Catalan language) - universals, generals and speciales - and it defines populus, constitutio populi, imperium and contrafaccions. Catalan legal instruments related to the enactment of laws by the General Courts-Constitucions, Capitols i Actes de Cort - and the limited power of the King, the composition of Generalitat (the General of Catalonia), and the role of the three Catalan branches (braços, estaments) are also elucidated. It also delves into the procedure for establishing constitutions which was followed by the Cort General of Montsó of 1585. The 15th c. legal compilation called Llibre dels Quatre Senyals and the recent discovery of the Llibre dels Vuit Senyals allow a more accurate dating of origins (1289, 1291, 1359, 1376), and a better understanding of its financial objectives, procedures and protections. Finally, this article introduces the notion of a dual conception of the political community as a suitable interpretative thesis to make sense of the whole process of the development of public law in Medieval Catalonia.
\end{abstract}

Keywords: Pactisme, legal pactism, pact-model, jurisdictio, senyoria, Medieval Monarchies, Corts Generals, Generalitat, Cort General de Montsó (1585), finances, legislative power, dual conception of political Community

Acknowledgements: Project IEC PRO2018-S05. Models del dret i la filosofia política catalanes: semàntica de les doctrines juridicopolítiques del pactisme en les seves diferents fases [Models of Catalanpolitical philosophy and law: Semantics of pact-model driven political and legal doctrines at their differentstages].

Disclosure statement: No potential conflict of interest was reported by the authors.

License: This work is under Attribution-NonCommercial-NoDerivs 3.0 Unported (CC BY-NC-ND 3.0)http://creativecommons.org/licenses/bync-nd/3.0/

Suggested citation: Montagut, T. de, Ripoll, P. (2019-2020). "Pactism in Catalonia: A Dual Conception of thePolitical Community", Journal of Catalan Intellectual History 12: 8-24, DOI: 10.2478/jocih-2019-0012. 
In the year 1954 the father of the new and modernized Catalan historiography, Jaume Vicens Vives published a historical essay called Notícia de Catalunya whose $5^{\text {th }}$ chapter was on the topic of pactisme ${ }^{1}$ (aCatalan pact-based model) (Vicens Vives 1954). Vicens's book became a classic, a work of reference for those who wished to learn about Catalonia's social spirit and the mentality that shaped its identity as a people. As a matter of fact, the book changed its originally conceived title Nosaltres els Catalans (We the Catalonians) due to the active Francoist censorship at the time and it would only appear as a subtitle to thesecond edition.

In this second augmented and corrected edition ${ }^{2}$, the chapter on pactism was found in the section les il.lusions (the hopes/dreams), following Vicens Vives's new tripartite division between: (i) "The elements": the Catalan language, the land, tools and toils, leading social classes and the Catholic Church; (ii) "hopes": pactism, empire and freedom, Hispania; and (iii) "difficulties": the State, revolutions and collective psychology.

This general view on pactism as a mentality was construed as a hopeful and collective choice of the Catalans which would help explain in part their communal or national history from the Medieval times up until now. Pactism acquired political transcendence when it gave historical and legal significance to Catalonia's position within the whole of Spain. Nevertheless, it is not this updated version of pactism as a generic category that we are primarily interested in as a research group focused on discovering the significance of pactism within European legal culture. We are after the one Professor Víctor Ferro called specific pactism, i.e., "the institutional doctrine and practice, characteristic in varying degrees of all the Medieval, and part of the Modern West, which, as has precisely been said, found for centuries in Catalonia its most consistent consecration and its most elaborate formulation, or at least one of the most elaborate" (Ferro Poma 1987: 137-138 and 1989).

As is well known, in the High European Middle Ages the increasing ruralization of society which had been occurring since the latter period of the Western Roman Empire (which disappeared in 476), produced a crisis of the general public power of the Germanic monarchies and the explosion of feudalism based on thepolyarchy of noble and ecclesiastic barons.

It is in this context, beginning in the $8^{\text {th }}$ century, that a subjective conception of the law will become hegemonic (Orestano 1987: 323ff). The Christians and their totalitarian experience of the faith produce theocentric societies. God is all powerful — of natural and supernatural forces - he is Pantocrator, creator of all things and thus, also of the law.

On the other hand, we find a blurring in those times between natural law and positive law. The law is located within the individuals, who are empowered to discover, declare and affirm their own law for themselves, as is seen on the motto of the United Kingdom of Great Britain and some of its coins, "Dieu etmon droit". When one is unable to affirm one's own right directly, be-

\footnotetext{
${ }^{1} N$. from the T. From the Catalan word "pacte", meaning "pact". Referring to the way of politics specific to the Catalan pact-based model. Customarily kept in the original form by Catalan scholars in their English writings. On the historiographic precedents and consequences of the concept of pactism elaborated by Vicens Vives, see Baydal Sala (2016).

${ }^{2}$ In the second edition in Catalan, the author incorporates three new chapters (Catholic Church and clergy, Hispanic attitude and the Catalan people and the minotaur) and others are reformed (Vicens Vives 2010 [1960]).
} 
ing there a litigation or a conflict of pretensions with other subjects who affirm opposite rights, high medieval men have three possible alternatives to solve the controversy: (i) applying direct force in order to impose his will as a right in a private war o with a blood revenge, all these manifestations of either a self-tutelage regime or vindicatory justice (Terradas Saborit 2019: 10-12); (ii) bringing the cause to the attention of the elderly or the best in the community (noblemen, ecclesiastics and/or notables) so they can evaluate the ordinary proofs or, in case they lack, the ordeal evidence, given that they are the ones who are most familiar with the uses and popular customs of the territory; and (iii) negotiating an agreement with the opposing party and formalizing the result in some communie o convenientie, i.e., in certain pacts that are a product of a given negotiation which will be sealed with a swearing to mutual allegiance (Montagut Estragués 2005; see also Kosto 2001:19-26).

It is in these feudal pacts based on the faith that peace is restored; that wars take place, spoils of war and territorial conquests are shared out; that there is an end to violence and conflicts between feudal lords and their groups of vassals, of loyalist, of men, of relatives bond by affinity kinship or of cognates forced by ties of blood or of land; it is in all of these conventional legal concepts where we are able to find the origins or most immediate precedents of medieval European pactism. It is the view of pactism as the political institution of certain ascendent social powers based on negotiation and consensus ${ }^{3}$, true, but also based on reicentrism ${ }^{4}$ and on the linking of people in the order of things. It consists in an intersubjective agreement among the parties which act bona fide and commit themselves to observe the agreements reached as rights. They oblige themselves freely and voluntarily. In other words, this agreed law is an elet (election) of theirparticular will, free and subjective, that can be annulled if the pact's good will reciprocity is broken by an offense committed or a wrongdoing, by not observing the usages and customs of the community. ${ }^{5}$

With the Gregorian reformation of the Catholic Church promoted by Pope Gregory VII, laid out in his Dictatus Papae (1075) (Berman 1998: 99-102), and with the birth of the University of Bologna at the end of the $11^{\text {th }}$ century, there takes place a renovation of the legal science by legal scholars who will study and interpret a rediscovered Roman civil law. A law which the emperor Justinian had had compiled in the $6^{\text {th }}$ century and which had been forgotten and not been usedor rarely - up to that point. It is a new civil law (Feenstra 1994: 179-210) which will be supplemented with canon law (Pergiovani 1994: 211-237) and which will soon be called ius commune due to its jurisprudential interpretation. This new civil law happensto be ideal for urban societies that are reviving and emerge strongly in a Christian Europe, kindled by a strong economic and

\footnotetext{
${ }^{3}$ Cfr. Grossi (1996: 246): "Nevertheless, we must clarify: consesualism is still far in the horizon and it will take an important anthropological revolution - the Humanist one-for it to find the necessary soil to grow in; it will then become the soil of a new legal experience separated from the one that precedes it thanks to a new view of the relationship between subject and cosmos and the role of the former within the latter." A different view, criticized by Grossi, which locates the roots of consensualism in Medieval times in Calasso (1959: 147).

${ }^{4}$ Cfr. Grossi (1996: 89-92). With this concept, the author, Professor Paolo Grossi, wants to point out that the high medieval societies revolve around things (res), that it is not men who create the roots of the land and consider it their property, it is the land and the bloof that attract and tie people over time and subordinates them to the larger familiar ties, to their lineage and also to their material patrimony.

${ }^{5}$ Later on the very Francesc Eiximenis (1330-1409) will evoke this old practice when he advises that "princes and peoples have to be loyal to each other". For more on this see Eiximenis (2009: 146). It is an updated version as far as language goes but a very free interpretation from a legal standpoint. In this sense it is best to consult the 1499 edition (Eiximenis 1499).
} 
demographic growth that began towards the end of the $11^{\text {th }}$ century and coincides with the first Crusades of feudal knights aiming at recovering the Holy Land.

The Crusades will open up again for marine merchant traffic the Mediterranean routes once blocked by the Muslims, at the same time that there begins a process of transitioning from feudal, local or regional polyarchies to Christian monarchies, which organize general communities based off recovering the notion and practice of public power. The new schools of Aristotelian-like thought will foster the conviction that nature, created by God, presents a rational configuration of things and their universals, which allows humanreason to know or apprehend them through concepts.

This new ideology would entail the first legal scholars of Bologna (the glossators) overcoming the subjective and particular conception of law and the establishment of a doctrine that implies an objective conception of the law according to which the law is immersed within the things, cases and causes. This rationalist conception will legitimize the rebirth of the public power in three significant dimensions: (i) the universal one (the Papacy, the Empire, the Unification of some kingdoms); (ii) the general one (Christian monarchies); and (iii) the special ones (municipalities and local or district manors, schools and personal corporations or guilds).

The new school of legal thought, which will gain renowned success starting in the $12^{\text {lf }}$ century and will become hegemonic during Modernity, will distinguish between the natural Christian law established by God in nature and positive human law established by the monarchs and, if need be, by the populus and their representatives within society or in the institutions. From this standpoint, man regains the ability to create law that had once been denied to him on the grounds that only God could legislate.

Nevertheless, human positive law is subordinated to the Christian natural law, in a similar way in which ajurist is subordinated to a theologian or in which the laws of the monarch or of the Courts would be subordinated to the precepts of Christian moral theology. The political model of the emperor Justinian (527-565), which conveys the Roman law, is that of a monist monarchy (the king is the exclusive representative of the kingdom, by the grace of God), an absolute one (the king is excused from following of the law) and Caesaropapism (the king is the head of the Church in his kingdom).

On another note, the doctrinal and dogmatic construction regarding public power, which are elaborated by the ius commune jurists, rests on the political-legal concept of iurisdictio ${ }^{6}$, which was the equivalent in the times' vulgar Catalan language to the term senyoria ${ }^{7}$ which Francesc d'Eiximenis used in his work Regiment de la Cosa Pública (1383) (López-Amo y Marín 1946: 85ff). We find in Digest (the work by the emperor Justinian which compiles and organizes the ju-

\footnotetext{
${ }^{6}$ Regarding this legal concept, see the structuralist and semantic analysis by Pietro Costa (2002 [1969]).

${ }^{7}$ Cfr. Eixemenis (2009: 77): "The first proposition is that cosa pública (res publica) is a community of gathered people who live under one same law, one same lord and one and the same customs, regardless of whether it is a kingdom, city, town, castle or any similar community which as more than a single house." Nevertheless, the version from the incunable edition is better and his reading of the words in bold (which is my doing) is particularly good. See Eiximenis (1499: f.13): "The first, being that res publica is some community of gathered people who all live under one same law and lord and customs regardless of if this gathering is in the form of a kingdom or a city or a town or a castle or any similar community which is not one single $\cos a$ (thing)". It can be found at: http://www.antiblavers.org/galeria/albums/userpics/10223/Regiment_de_la_Cosa_P\%C3\%BAblica_1.pdf
} 
risprudence of the Roman jurists from the classical period- from the $3^{\text {rd }}$ century b.C. to the $3^{\text {rd }}$ century a.D.) the glossa potest by Accursius (c. 1185- c. 1263). From this we learn that iurisdictio refers to public power, one with competences to act on positive right in legislative, judicial, governmental and gracious matters, in accordance with the Christian natural law (Zeller 1966, I: 123). In spite of this, as we have already hinted at before, iurisdictio, we find, can have varying degrees and levels which are not clearly structured in a hierarchy and are not always subordinated from the top down; they maintain some symbiotic or coordinate ${ }^{8}$ relationship between them. Thus, as we have mentioned before, we can distinguish between:

(i) iurisdictiones universales. These belong to the Church and to its institutions as well as to the Christian empire. They are represented legally by the official and/or effective ius commune. Afterthe wars of investiture between the Pope and the Empire (during the $11^{\text {th }}$ and $12^{\text {th }}$ centuries), theimperial project fails. The final defeat can be seen in the treaty or concordat of Worms of 1122 which will end it. The Union of kingdoms and lands of the royal Crown of Aragon will also invokethe iurisdictio universalis ${ }^{9}$;

(ii) iurisdictiones generales. These belong to the lords and monarchs who have no superior temporal power; they are at the vertex of the feudal pyramid of their territory. As a matter of fact, these Christian monarchies will soon demand a supreme iurisdictio and will de facto seal their territorialcompetences by receiving the ius commune and developing the iura propria, the legal concepts from the various regalies ${ }^{10}$. The interactive duality between King-Kingdom, Prince-Princedom, Duke-Dukedom, Count-County or similar, and their concrete historical experience, will allow for the conformity and validation of two quite diverse models of political organization: (i) monists (cases like France and Castille); or (ii) dualists (such as the case of the territories of the Crown of Aragon or in England) depending on the exclusiveness or sharedness, respectively, when it comes to the titularity of the iurisdictio generalis. The iurisdictio generalis will represent the political expression of a general community with a differentiated cultural national core, that is, a populus, which in Catalonia is expressed as an organic unity ${ }^{11}$ and in its legal formulation, as the Universitas Cathaloniae in the Courts of Barcelona of $1283^{12}$;

(iii) iurisdictiones speciales. These were the local or regional areas (municipalities and baronies) or the personal one (guilds, brotherhoods, commercial consulates, corporations, etc.). All of these were also structured as organic unities or universitates.

In all these political European societies, the legal dimension is above the political one. The

\footnotetext{
${ }^{8}$ Cfr. Eiximenis (2009: 81). Based on St Paul's organicist view on the human body, the Res publicha is conceived as the putting together of its members in a similar way to the members of the human body are put together: "So he says: See where a member is naturally found alive in a body, observe its shape and you will see, firstly, that the bond between them is such that one serves the other diligently, and all it does is useful for the others".

${ }^{9}$ About this extreme case, see: Vicens i Vives (2010 [1960]: 141-144); Montagut Estragués (2013: 104); Palomo (2019).

${ }_{11}$ About the concept and content of the regalies in Catalonia see Lalinde Abadía (1964: 320-327).

${ }^{11}$ Cfr. Marsilius of Padua's vision (c.1275 - c.1343) of the populus "as a totality composed, ordered and intrinsically differentiated" in Costa (2007: 49).

${ }^{12}$ Cfr: Cortes de los antiguos reinos de Aragón y de Valencia y Principado de Cataluña publicadas por la Real Academia de la Historia. Tomo I: 142. As for the representation of the populus as universitas, see Costa (2007: 47). An explanation for this evolution in Gouron (1996).
} 
monarch itselfand his officials are obliged to keep the law. This is why there is no absolutism understood as a total irresponsibility on the monarch's part, who would be excused from following the law. Notwithstanding, from the end of the $15^{\text {th }}$ century and during the $16^{\text {th }}$, the situation undergoes a substantial change due to the irruption of Renaissance and modern philosophical thought, which will produce the so-called anthropologicturn and the political and legal Humanism with the birth of the mos gallicus and the notion of political sovereignty, foundations for the absolute State and their successor, the liberal constitutional State.

If we apply this jurisdictional outline to the Crown of Aragon and to Catalonia, to be precise, we can assess the existence within Catalonia of a plurality of jurisdictions: two universal ones (the ecclesiastic one and the one of the royal Crown), a few generic ones (the monarch's and the one of the General or universitas from every territory: Catalonia, Aragon, Valencia,...) and many special ones (as many as were the demands or the ones used by the municipalities or lordships and other universitates or smaller existent entities). Also, in the Crown of Aragon, the relationship among these jurisdictions, or among the different multi-layered public powers, was one of coordination and one of a symbiotic nature more than of a strictly hierarchical one ${ }^{13}$.

The resurgence of the legislative power that was brought about by the use of the iurisdictio generalis by the monarch, stumbled in Catalonia against the decisions of the Courts of Barcelona of 1283, which prescribed the obligation of the monarch to produce the general constitutions and the agreement statutes together with the approval of all three general government entities of Catalan society, as well as the approval of the better part of their representatives summoned and gathered in the Assembly of the Courts. This is the expression in Catalonia of a dimension of the European legal culture which Paolo Grossi has highlighted by remembering that the true protagonist of the community is not the rex but the populus: "It is [the populus] who holds the normative power par excellence: the lex is above all else, consitutio populi, bound to the consensus of the community" (Grossi 1996: 199). The monarch issues laws on his own is an exception to the standard procedure which attributes the legislative power "to the community, the plurality organized in the unity" (Grossi 1996: 201). This was one of the fundamental principles of the Catalan political constitution of the moment: the legal pactism. In order to establish the general law of Catalonia (Constitucions or capitols de Cort) there was the need for a negotiation between the king and the Catalan governing entities during the time when the Courts were being held, as well as a final agreement on both parts.

The other fundamental pillar of the medieval and modern political constitution of Catalonia was the principle of the law's empire (imperium, medieval rule by law). That included everyone, even the monarchs themselves were to be bound by the Catalan law, insofar as the predominant objective conception of the law implied the conviction that the law is not created but proclaimed - ius dicere - as a consequence, since it ensues from a natural order preestablished by God, it bounds all (Costa 2007: 54; Montagut Estragués 2019).

This constitutional design meant that Catalonia had established itself as a dualist monarchy, in which the general community was represented at its highest level by the prince and by the cor-

\footnotetext{
${ }^{13}$ This symbiotic relationship can be seen as a relative hierarchy instead of an absolute one. On this topic, see Costa (2007: 45).
} 
poration which represented the principality, that is, by the General or universitas Cathalonie and its representative organs: the governmental entities or estates of the Courts and the Diputació of the General or Generalitat. The relationship between the two general powers was based on allegiance. This allegiance was formalized by the monarch's preceding oath to keep the Catalan law, a condition sine qua non for the king to establish histitle of iurisdictio generalis in Catalonia and, afterwards, with an oath of obedience and allegiance on the part of the Catalans.

In this regard, in order to make effective the law's imperium in Catalonia, it was necessary for the General to have a compilation of the general Catalan law (Montagut Estragués 1995), to have financial autonomy in order to negotiate the donation to the monarch which was due during the holding of the Courts (Sánchez Martínez and Ortí Gost 1997: VI-IX) and it was also necessary for him to have an independent justice administration with the ability to impose the law on the monarch and his officials (Montagut Estragués 1999 and 2008).

The compiling process of the Constitutions and of the other Catalan law, as well as of the privileges and rights of the General, began in the early $15^{\text {th }}$ century and has been thoroughly studied by other scholars (d'Abadal i de Vinyals and Rubió i Balaguer 1910; Font 2004 [1988]; Álvarez Gómez 2016; Ripoll Sastre 2018).

The recently tracked Llibre de Vuit Senyals (LVS) and its transcription and analysis prove to us that the rules of the Generalitat were clearly an object of compilation even before the writing of the Llibre dels Quatre Senyals (LQS) ${ }^{14}$. We also learn from it that this process was linked to the general compilation we have previously mentioned which would have hardly ignored that the institution most representative of the emancipation of the estates due to its crucial role in the defense of political dualism and legal pactisme, the Generalitat, would have escaped such compilation principles and would have taken a back seat with regards to other constitutions and law of Catalonia. The goal of the LVS had been to put together a compilation of all of the fundamental norms which constituted the legal system of the delegates of the General of Catalonia. The content of this compilation made it possible to draft a treatise on the legal and political nature of the Generalitat. This treatise would need to prove that the institution was not a subtle estate commission with an arbitrary duration, as Ferran I Trastàmara had insinuated, but that its practical origin had enabled the creation of a political space which had continuity in time. The law and more specifically the LVS - which turned into an instrument of reaffirmation of institutional autonomyshowed that it was impossible to tear down this political arena which rested on the bases of legal pact-making and political dualism, both of which configured the mentioned symbiotic structure of the public or jurisdictional power of the principality of Catalonia and by extension of the Crown of Aragon.

The LVS proves that in the early 15th century there is an understanding that the legal bases of the institution are found in 1359 - although the precedents of 1289 and 1291 are taken into account - and shows which moment is considered to be most representative of the legal and admin-

\footnotetext{
${ }^{14}$ This document, which was widely spread after being printed for the first time in 1634, is a compilation of the regulations which governed the Generalitat since its reformation in 1413. Tomàs de Montagut in studying it closely developed a hypothesis according to which the Llibre de Vuit Senyals (which was missing although it appeared referenced in documents of the 16th and 17th centuries) should have contained the regulations corresponding to the time period of the creation of the institution and, therefore, prior to 1413 (Montagut Estragués 2006: 16).
} 
istrative development of the institution during the period of its consolidation: the Courts of 1376 . The legal concepts laid out in the manuscript are informative of the contractual relationship existing between the king and the estates which moved towards displacing political monism at a time in which the cessante causa cessat effectus clause was well in place, as were the conditions under which the king would lose the aid offered to him by the estates, as is seen for instance in the chapter 14 of the Cort of $1359^{15}$. Financial autonomy was being secured by limiting the monarch's actions in the powers provided by the ius commune, the disposition 35 of $1359^{16}$ establishes limitations on prerogatives such as the motu proprio principle, the royal mercy or pardon, remission (pardoning debts), acquittal (halting legal procedures), alongament (postponing payments) or empara (self-serving embargos): in sum, checked powers which represented anti-absolutist measures. The distinction between ordinary legal jurisdiction, regulated by the law, and delegated jurisdiction, the one that was susceptible to the king's abuse of power, is pervasive throughout the LVS; that is why chapters such as the 14 of the Court of $1373^{17}$ prevented the king from naming judges ad hoc during the subsidy or donation of the estates in those ordinary jurisdictions which interfered with the independence of the ongoing procedures of those jurisdictions, with only three exceptions: crimes of lese-majesty (treason, rebellion, sedition, etc.), false coin or sodomy. As we will see, these measures are found in the majority of the Courts of the LVS.

It is worth noting that the dualist system not only implied the limitation to the king's possession of the contributions made by the estates, but it would directly prohibit accessing and spend it, since the execution would rely on a decision of the Court and only by those appointed by it (disp. 16 de 1373$)^{18}$, at a time in which the royal family and its entourage had already been subjected to tributes some years prior, placing the monarchy under the law (disp. 4.71 de 1365) ${ }^{19}$. At the same time, fiscal autonomy was being established through standardized administrative procedures such as the precepts of the chapter 16 of $1365^{20}$ which posed two different procedures: on one hand, the obligation of collecting and managing the money as a jurisdiction exclusive to each estate individually - given the divergence in interests according to their representativity in the community - yet, on the other hand, the expenses of this collection would be joint, and in being thus integrated, it would become the transversal element, common to all. And so, the collecting represents the different interests of the estates within the General, turning it into a reflection of the estate regime; whereas the expenses represented the overcoming of this regime, making it so the distribution hada solidarity component which produced a joint management system.

\footnotetext{
${ }^{15}$ In this specific instance, those were: 1) in the case of the application of peace and truce for over two years; 2) if the truce were of one year or less the aid would still be collected and kept by the deputies, who would hold on to them for war affairs if the war returned within the following two years or even a third; and 3) if the truce was over a year but under two, the aid would be collected for one year and would be then be acquitted, yet if the war returned, the aid could be collected again for up to two full years. The key to this provision at that time was that there were two years of time to collect the aid, therefore, the provisos revolved around those two years. The provisions came with other provisos as well such as the need for the king to swear to the Archbishop of Tarragona under penalty of excommunication (veto sentencing) that he would not use the money from the treasury for private matters or that any proceeds that were not destined to the war could be used for other public policies. LVS, ff. 74ra - 74va. Vid. M. Sánchez on the period of the Catalan fiscal system's construction (1288-1345) in which this principle appears, a period that Henneman calls "war financing" (Sánchez 1992: 367).

${ }^{16} \operatorname{LVS}$, ff. $77 \mathrm{v}^{\mathrm{a}}-77 \mathrm{v}$.

${ }^{17} L V S$, ff. $98 \mathrm{v}^{\mathrm{a}}-99 \mathrm{r}^{\mathrm{a}}$

${ }^{18} L V S$, ff. $99 \mathrm{r}^{\mathrm{a}}-99 \mathrm{v}^{\mathrm{a}}$.

${ }^{19} L V S$, ff. $129 \mathrm{v}^{\mathrm{b}}-130 \mathrm{r}^{\mathrm{a}}$.

${ }^{20} L V S$, ff. $134 \mathrm{v}^{\mathrm{a}}-135 \mathrm{r}^{\mathrm{b}}$.
} 
This inchoate vision would end up in the General being identified as a public corporation in posterior Courts, as a result of the development of some political assemblies which appeared as a product of a war-oriented economy, which guaranteed the right to consent to the tribute, the right to participate in the elaboration and sanction of the law, the right to celebrate these meetings periodically, the election of the representatives of the third estate in a so-to-speak quasi democratic way, the control over the royal officials and the participation in the exercise of the sovereign justice (Hébert 2014: 254).

The LVS compiles the particularities of all of these principles, as can be seen in the chapter 87 of $1376^{21}$ stablishing a conditional subsidy offered after a legal redress of grievances (also developed in other dispositions such as the chapter 14 of $1378^{22}$ which imposed that redress by judicial means and, therefore, through a judicial sentence and not by the arbitrary way of government, a crucially binding aspect for pactisme), with the gratuity of the administrative acts and the enaction of the constitutions at the request of the estates and not of the king.

This dynamic involved the multiplicity of subjects dealt with in the Courts which appeared in the LVS. It shows the interest of the estates in regulating subjects on penal, naval, military or procedural law, with strong measures destined to prevent tax evasion as a result of a strong taxation system, which would have been difficult to attain without a legal structure common to all the estates. The discovery of complex financial procedures will end up in a debt which, on one hand, will cause a problem but on the other, it will generate a system which will benefit from the Generalitat's tributes. Moreover, this will promote the development of a policy of economic unity and common market within the Crown of Aragon, as can be seen in the ordinations on taxation, which is favorable to these tributes and which, in the end, will allow the continuity of the Generalitat given the political failure of the repayment of the debt.

The LVS is, thus, the representation of the construction of the powers of the Generalitat, and an accurate portrait of the articulation of the Catalan political system through a dualist monarchy, built by way of legal pactism. On another note, it is significant that the LVS (with the 1413 regulations) disposes not only the rights of the General, but also the obligations of the monarch (in which the role of the oath is crucial), and according to which, as has been said already, it becomes a right of the General that before swearing allegiance to the king he has to have necessarily sworn the general law of the principality ${ }^{23}$. That law is the one that limits his plenitudo potestatis and enables, thus, the jurisdiction of the Generalitat.

Professor Víctor Ferro studied the main elements that configured the legal doctrine on pactisme in Catalonia and other parts of Europe using as his source the Catalan legislation in force in 1715/16 and the Catalan judicial and doctrinal jurisprudence that appeared in the work of Catalan jurists published during the $16^{\text {th }}$ and $17^{\text {th }}$ centuries (Ferro Poma 1987: 289-292). He also used the bibliography which established the state of the question at the time of the writing of his book (1985) as well as some documentary sources. In his work, Víctor Ferro addresses some of the fundamental issues which make up the mesh that is institutional pactism in Catalonia: the Corts, the Generalitat, the co-legislation power of estates, the defense of the law and the contraventions,

\footnotetext{
${ }^{21} L V S$, ff. $36 \mathrm{r}^{\mathrm{b}}-37 \mathrm{r}^{\mathrm{a}}$

${ }^{22} L V S$, ff. $43 \mathrm{r}^{\mathrm{b}}-43 \mathrm{v}^{\mathrm{b}}$

${ }^{23}$ For a thorough view on this question, Bajet Royo (2009).
} 
the interpretation of the law, the principle of civil liberty and the Tribunal de Contrafaccions (a Court for all actions against the law) (Ferro Poma 1987; Capdeferro i Pla and Serra i Puig 2015a).

As for the Catalan Corts, they hold the most relevant ceremony of pactism, the one that establishes the general Catalan law. The jurist Lluís de Peguera (1560-1610), following in part the work of Jaume Callís (1364/70-1434) (Callís 1518), wrote a booklet which was published posthumously in 1632 and was reeditedin 1701, called Practica, forma, y estil, de celebrar Corts Generals en Cathalunya, y materias incidents en aquelles (Practices, form and style of celebrating the General Courts in Catalonia and matters incidental tothem) (Peguera 1701). This work is an elementary exposition of the Catalan parliamentary procedure by which the general law of Catalonia is established. The procedure guarantees parliamentary freedom because it requires following the procedures in a timely and organized way: (i) royal summoning; (ii) the king's initial proposition and the response by the estates' representatives; (iii) the election of the estate positions; (iv) the oath; (v) the authorization process; (vi) the dissent; (vii) incidences of the king; (viii) the grievances presented to the monarch; (ix) the constitutions and the Court chapters; (x) the ending and conclusion of the Cort.

This procedure of Catalan parliamentary law shapes the structuring principles of pactism: the rule by law and of legal pactism; the latter coming into effect by orienting and encouraging the production of the Catalan constitutions and laws by way of negotiation, treatment and contract between the king and the threeCatalan estates of the Catalan General. ${ }^{24}$

Therefore, if we look into the procedure for establishing constitutions which was followed by the General Court of Montsó of 1585, we will see it follows these steps:

I. It is customary to appoint a commission of 18 people (six per estate) which meet in a house located outside the place where the estates meet, to deal and write down in memorandums or notebooks the chapters of the constitutions which must be considered and approved by the three estates.

II. Then, these chapters are read in each estate which will formulate amendments or notes that are considered pertinent by the members of each estate as they expose their opinion in corresponding the election.

III. Next, the procedure is to combine the notes and amendments made within each estate.

IV. The promoter of each estate refers to the others the results of this combination.

V. Then, the three already combined documents are combined and agreed upon.

VI. Insofar as the resulting document pleases the majority, the chapters of the constitutions are passedand approved by the three estates.

VII. The chapters of the constitutions, already having been passed by the three estates, are pre-

\footnotetext{
${ }^{24}$ These principles were well known during the seventeenth century, as highlighted by Joan Pere Fontanella, Decisiones SRSC, dec. 283, 7, p. 528: "Quia in Cathalonia Rex solus non condit leges, sed Rex cum populo, et eis adstringitur Rex sicut caeteri, et eas iurat se observaturum in ingressu sui regiminis in vim Const. 2. tit. de iuram. ax. volun. comm. necessari. et idem cavetur aliis etiam constitutionibus..."
} 
sented tothe king together with a supplication that he might decree them.

VIII. The King or, in his name, the tractadors (officials who mediated between the king and the estates), grant the first decrees to the chapters of the constitutions supplicated for by the estates. These decrees can consist in giving the quite simple Plau al Senyor Rei, "It pleases His majesty", or maybe to grant it with a manifestation of a vaguely approximate expression of this will, whichmay even be negative or incongruous with that which has been supplicated for. At times, the kingresponds with a manifestation of his own will more or less congruent with that which has been supplicated for by the three estates yet without manifesting the "It pleases His majesty".

IX. Next up, the first decrees of the King are treated by the three estates in the same way as the initial memorandums or notebooks from the chapters of the constitutions; and then they finally present to the monarch their replies and acceptances to the first decrees, which may consist either in purely accepting the decree of the monarch or in asking the king to reform, improve or enable the first decrees or, perhaps even, to ask the king to command a decreed chapter to be erased.

X. The monarch proceeds, usually through the aforementioned tractadors, to decree the first replies pleaded by the three estates, giving way to the second decrees which may consist in: granting the "It pleases His majesty" (purely or conditional); in ratifying the first decrees stating that "There is nothing to be changed"; in manifesting his will freely; or in granting "it shall be erased".

$\mathrm{XI}$. Once the second decrees have been communicated to the three estates, they proceed to formulate the second acceptances and replies.

XII. The monarch proceeds to grant the third decrees to the second acceptances and replies in a wayanalogous to the previous ones (Montagut Estragués 1998: XL-XLI).

The jurist Andreu Bosch (1570-1628) maintains that in the Cort General de Catalunya there is present the Republic or mystical body of Catalonia, that is, the Catalan populus configurated or institutionalized as the Principat de Catalunya (Principality of Catalonia), comprised by the king as head (the prince) and the braços (arms) or estates. Nevertheless, these estates could also be conceived of as members of the populus of Catalonia (the Principality, specifically, without including the king), which constituted the General of the country, that is, the Universitas Cathaloniae. In sum, there would be only one populus of Catalonia but with two different persons: the first República general per tots ("general Republic for all") which consists of both the king and the estates; and the second Republic which comprises only the estates. This bi-republican doctrine, valid in Catalonia, is that which allows us to affirm its political constitution as a bluntexample of the model of dualist monarchy, founded on the principles of the early rule of law and legal pactism (Ferro Poma 1987: 137-138, particularly n. 1). The General or its permanent Deputation-later called Generalitat - dialogued and negotiated with the king and swore to him allegiance and obedience which were not only not unconditional but the very opposite, they were expressly conditioned to the king's keeping of the Catalan law.

The constitution Volem, estatuïm e ordenam (We will, we rule, and we order) of the Courts of 
Barcelona of 1283 establishes a true collegiate power of the estates and the king. These "pacts override the legislative power of the prince and they limited it" (Ferro Poma 1987: 191).

If we take a look at comparative law, we will see other equivalent co-legislative powersalbeit in a later period than in Catalonia - in Aragon (1301), Valencia, Castille (1387), England and Germany; in France, conversely, the Estates General could never put it into effect (Ferro Poma 1987: 192 and 442ff). Yet, even more important than declaring the principle of the rule by law, was to attain its effectiveness through the institutionalization of organs and procedures of control. "Compliance, the key to Catalan law" (Capdeferro i Pla and Serra i Puig 2015a: 38-52) is the title Professor Josep Capdeferro and Professor Eva Serra give to the chapter that discusses "The pacted law of Catalonia and its perception; the consummation of the secular process of Compliance" (Capdeferro i Pla and Serra i Puig 2015a: 43), and the "Contraventions, grievances, inspection: Communicating vessels" (Capdeferro i Pla and Serra i Puig 2015a: 50). All these mechanisms and institutional procedures had the shared goal of defending the Catalan legal system as well as the rights that comprised it. Among them the pacted law at the Courts, expressed in the shape of the Constitutions, the chapters of the Court and acts of the Courts stand out due to their particular relevance. The chapter of the Court, passed by the king Martí and by the estates during the Courts of Barcelona in 1409 and the constitution of the Courts of Barcelona in 1599, list in an ordered way - and even in a prevalent one - the sources of law that constitute the Catalan legal system. In neither of these provisions is there any mention of a source of the general Catalan law of an exclusively royal production.

There is no room for pragmatic sanctions, nor provisions, nor edicts. The intervention of the King must be channeled through the Courts in which he has only a co-legislative power which must be completed with the consent of the estates, with the pact. The King does not have primacy in the creation of law and this is confirmed by the aforementioned disposition of 1599 . The King's private legislation must never derogate pacted law.

If we compare this system to the one in Castille we will see that the way of solving the same problem is quite different there. Since the $14^{\text {th }}$ century, it is aimed at endorsing and solidifying an absolute monarchy. In Castile, the "Ordenamiento de Alcalá" of 1348 - later qualified by the "Ley primera de Toro" of 1505-establishes a true order of legal source preference which grant to the privative monarch's legislation — which the Courts can't derogate - a primal spot in the ranking of sources. In second place, and in the case of a lack of a general rule, the local municipal rights can be invoked, yet these could be modified by the King and there would be the need to prove that they are still in use in order to be duly invoked.

In the third place of the order or preference we find the Partidas, the Castilian version of the ius commune, a royal law which synthesizes and filters the Empire's law and that of the Church through the Castilian language and nature.

Finally, it is also the King who will be authorized to interpret the entire system and fill in gaps with new dispositions.

As we can see, in Castille the King is not bound to any superior or inferior political power. His will can bedirectly translated into a law which binds the entire kingdom. There is no social power that can legitimately oppose their own law to a law of the King. That explains why in Castille 
judges were not forced to display the reasoning and grounds of the judgments. Everything leads to an absolute monarchy.

In Catalonia (like in the rest of the Crown of Aragon) the situation, as we have seen, was quite the different. The leading social estates were directly linked to the creation of the law:

a) through the legislative and political institutions (Courts and Deputation of the General).

b) through the recognition of the full force of the municipal and feudal law.

c) through the possibility of an interpretation and a direct invoking of the ius commune, equity andgood reason.

In the creation of Catalan law, pactism - designed in the Courts of Barcelona in 1283remains during the $15^{\text {th }}$ and $16^{\text {th }}$ centuries due to express ratifications of the monarchs, appearing in the Compilations under the title De observar Constitutions (On the observing of constitutions) and proving that the legislative sphere limits the absolute powers of the monarchy. Nevertheless, in judicial and executive matters, the King will attain certain absolute powers which will be gathered under the name regalia. This will produce a tension between absolutism and pactism, which will remain in Catalonia during this period, while in Castille it had already been resolved in favor of absolutism (Montagut Estragués 1989: 670-672).

The supremacy of the pacted law has as a corollary the invocation by Francesc d'Eiximenis of the old doctrine of tyrannicide, once formulated by John of Salisbury in the $12^{\text {th }}$ century, in order to include withinthe figure of the tyrant, besides the figure of a governor who governs absque titulo and the figure of the governor who governed with a title but serving a particular interest instead of the common good, the figure of a governor who governed infringing the law (Ferro Poma 1987: 271-272; Costa 2007: 57-58). As a consequence, this last one, by infringing the law, incurred in a contrafacció.

The Tribunal de Contrafaccions (1702/1705/1713) is the last mechanism that appears within a series of institutions aimed at ensuring the compliance of the Catalan law (Montagut Estragués 2008) and to reestablish the right that has been infringed. Professor Víctor Ferro in 1987 schematically (Ferro Poma 1987: 418-427) and in a broader and more thorough way, the studies of Josep Capdeferro and Eva Serra in 2015 (Capdeferro i Pla and Serra i Puig, 2015a, and 2015b) have analyzed the precedents, the organic constitution, the operation and procedures of this Tribunal created by the Courts de Barcelona in 1702 and reformed by the ones of 1705. Capdeferro and Serra have also studied the activity of the Tribunal up until 1713 through the specific cases they have been able to document. Nevertheless, in order to protect the violated Catalan legality, there had been established other previous court proceedings such as: the syndic of the Deputation of the General in 1413, a control by the Royal Audience in 1481 and by a mixt Tribunal composed of judges appointed by the king and by the estates, during the period of the French dominion (16401652).

The political constitution of the modern and medieval Catalonia based on the principles of legal pactism and the early rule of law had evolved, and its legal and institutional system updated inasmuch as was possible, given its belonging to a monarchy comprised by the Austrian dynasty 
and by the legal pathways that were open to them. The Tribunal de Contrafaccions became a good example of this institutional modernization of pactism that emerged within a society with hints of modernity, as Josep Capdeferro and Eva Serra pointedat:

The Tribunal de Contrafaccions came to be established in a Catalonia which was progressively more and more cohesive, with a territory which was articulated at the productive and mercantile level, where social advancement was working well enough (García Espuche 1998). A community with republican traits, horizontal strength, with a very extended idea of common good among the popular strata (Corteguera 2005) and with an elevated participation on public affairs. The frequent audits increased and reinforced the participation in such matters albeit not with the desired efficiency (Capdeferro 2007). It goes without saying that that world was not only filled with virtue, but also with defects and corruptions.

To end this quick and impressionist vision of modern and medieval Catalan pactism until its violent suppression by the military conquest of Catalonia by the Bourbon troupes in the beginning of the $18^{\text {th }}$ century(1705-1714), it is convenient to reproduce a part of the final evaluation of the history of Catalan public law by Víctor Ferro:

The Catalan institutions which attained such notable achievements both due to their novelty and to their absolute merits - sharing de facto the legislative power between the king and the country; subordinating all authority to the agreed upon law; direct binding of the officials to the legal system; political and legal custody of the legal and administrative system of a public treasury, which is different from that of the prince and is in the hands of a permanent representation of the estates; guarantee of personal security and so many othersculminate thus in procedures that fulfill in a practically unsurpassable way the implicit aspiration in all of them: the preservation of the principle of liberty under the rule of law, clearly defined and declared, if need be, in an impartial trial. (FerroPoma 1987: 449-450).

Translation by Wendy R. Simon

\section{REFERENCES}

[n/a] 1896. Cortes de los antiguos reinos de Aragón y de Valencia y Principado de Cataluña publicadaspor la Real Academia de la Historia, Tomo I (1064-1327). Madrid: Establecimiento tipográfico de la viuda e hijos de Manuel Tello. Retrived from: https://sirio.ua.es/libros/BDerecho/cortes_de_aragon_y_catalunya_tomo_I/ima0195.htm

Álvarez Gómez, D. 2016. Compendium Constitucionum Generalium Cathalonie de Narcís de Sant Dionís. Barcelona: Departament de Justícia de la Generalitat de Catalunya.

Baydal Sala, V. 2016. "Pactistes des de quan? Les arrels del concepte de "pactisme" en la historiografiacatalana i l'obra de Jaume Vicens Vives". eHumanista/IVITRA 9: 314-340.

Bajet Royo, M. 2009. El jurament i el seu significat jurídic al Principat segons el dret general de Catalunya (segles XIII-XVIII). Edició de la "forma i pràctica de celebrar els juraments $i$ les eleccions a la ciutat de Barcelona en el segle XV'. Barcelona : Universitat Pompeu Fabra, Seminari Permanent iInteruniversitari d'Història del Dret Català Josep M. Font Rius.

Berman, H. J. 1998. Diritto e rivoluzione. Le origini della tradizione giuridica occidentale. Bologna: IlMulino. 
Callís, J. 1518. Extragravatorium curiarum ... per dominum Iacobum de Callicio. Barcelona. Calasso, F. 1959. Il negozio giuridico. Milan: Giuffrè.

Capdeferro i Pla, J. 2007-2008. Promoció, edició i difusió d'obres jurídiques a Catalunya a cavall delssegles XIV i XVII". Ius fugit: Revista interdisciplinar de estudios histórico-jurídicos, 15: 537-559.

Capdeferro i Pla, J. and Serra i Puig, E.2015 (a). El Tribunal de Contrafaccions de Catalunya i la seva activitat (1702-1713). Barcelona: Textos Jurídics Catalans (Parlament de Catalunya i Departament de Justícia de la Generalitat de Catalunya).

Capdeferro i Pla, J. and Serra i Puig, E. 2015 (b). Casos davant del Tribunal de Contrafaccions de Catalunya (1702-1713). Barcelona: Textos Jurídics Catalans (Parlament de Catalunya i Departament de Justícia de la Generalitat de Catalunya).

Corteguera, L. 2005. “Sancho Panza Wants an Island”, Romance Quarterly 52: 261-270.

Costa, P. 2002 [1969]. Iurisdictio. Semantica del potere politico nella pubblicistica medievale (1100-1433). Milano: Giuffrè.

Costa, P.2007. "La soberanía en la cultura político-jurídica medieval: imágenes y teorías", Res Publica, 17 (2007): 37-59.

D’Abadal i de Vinyals, R. and Rubió i Balaguer, J. 1910. "Notes sobre la formació de les Compilacions de 'Constitucions i altres Drets de Catalunya i de Capítols de Corts referents al General”, Revista dels Estudis Universitaris Catalans, 4: 409-465.

Eiximenis F. 1499. Regiment de la cosa publica ordenat per lo reverent mestre Francesch Eiximenis. València.

Eiximenis, F. 2009. Lo regiment de la cosa pública en el Dotzè del Crestià. Madrid: Centro deLingüística Aplicada Atenea.

Feenstra, R.1994. "L'insegnamento del diritto civile a Bologna e la sua diffusione nell'Europa occidentale". In Gian Paolo Brizzi and Jacques Verger (Eds.) L'Università dell'Europa. Le scuole e i Maestri. Il Medioevo, Milano: Pizzi, pp.179-210.

Ferro Poma, V. 1987. El Dret Públic Català. Les Institucions a Catalunya fins al Decret de Nova Planta. Vic: Eumo.

Ferro Poma, V. circa 1989. "Algunes reflexions sobre el pactisme”. Unpublished conference at the University of Barcelona.

Font, J. M. 1988. “Estudi Introductori”. In Constitucions de Catalunya (1495): incunable of 1495. Ed., Josep Maria Font. Barcelona: Textos Jurídics Catalans (Parlament de Catalunya i Departament de Justícia de la Generalitat de Catalunya), pp. 33-75.

Fontanella, Iohannes Petrus. 1668. Decisiones Sacri Regii Senatus Cathaloniae, t. 1, Lió. Grossi, P. 1996. El Orden jurídico medieval. Madrid: Marcial Pons.

Gouron, A.1996. "Populus: legal entity and political autonomy”. Fundamina, a Journal of legal History, 2/2: 249-260.

Hébert, M. 2014. Parlamenter. Assamblées représentatives et échange politique en Europe occidentalà la fin du Moyen Age. Paris : Éditions de Boccard.

Kosto, A. J. 2001. Making Agreements in Medieval Catalonia: Power, Order, and the Written 
Word(1000-1200). Cambridge: Cambridge University Press.

Lalinde Abadía, J. 1964. La Institución virreinal en Cataluña (1471-1716). Barcelona: Instituto Españolde Estudios Mediterráneos.

López-Amo y Marín, A. 1946. "El pensamiento político de Eiximeniç en su tratado de 'Regiment dePrinceps"'. Anuario de Historia del Derecho Español, 17: 5-139.

Montagut Estragués, T. D. 1989. "Pactisme o absolutisme a Catalunya: les grans institucions de govern(s.XV-XVI)". Anuario de Estudios Medievales, 19: 669-680.

Montagut Estragués, T. D. 1995. "Les compilacions del dret general català". Glossae: EuropeanJournal of Legal History, 7:113-134.

Montagut Estragués, T. D. 1998. "Estudi introductori”. In Practica, forma, y estil, de celebrar Corts Generals en Cathalunya, y materias incidents en aquelles. Lluís de Peguera. Madrid: Centro de EstudiosPoliticos y Constitucionales.

Montagut Estragués, T. D. 1999. “La justicia en la Corona de Aragón”. In La administración de justicia en la historia de España: actas de las III Jornadas de Castilla-La Mancha sobre investigación en archivos. Guadalajara, 11-14 noviembre 1997. Guadalajara: Anabad and Juntas de Comunidades de Castilla-La Mancha, pp. 649-686.

Montagut Estragués, T. D. 2005. "Pactar i transaccionar a Catalunya : L'Usatge de Barcelona 'Communie et Convenientie"'. In Maria Teresa Ferrer, Jean Marie Moeglin, Stéphane Péquignot and Manuel Sánchez (Eds.), Negociar en la Edad Media/Négocier au Moyen Âge. Madrid: CSIC InstituciónMilá y Fontanals/Casa de Velázquez (Madrid), pp. 27-43.

Montagut Estragués, T. D. 2006. Llibre dels Quatre Senyals, Estudi introductori. Barcelona: EditorialBase.

Montagut Estragués, T. D. 2008. "El principi de l'imperi del dret i el control de la seva observança a la Catalunya medieval i moderna". In Remedios Ferrero Micó and Lluís Guía Marín (Eds.) Corts $i$ Parlaments de la Corona d'Aragó: unes institucions emblemàtiques en una monarquia composta. València: Universitat de València, pp. 559-568.

Montagut Estragués, T. D. 2013. "La Constitució política de la Corona d'Aragó”. In María Isabel Falcón Pérez (Ed.) El compromiso de Caspe (1412): cambios dinásticos y Constitucionalismo en la Corona de Aragón. Zaragoza: Ibercaja, Diputación General de Aragón, pp. 104-116.

Montagut Estragués, T. D. 2019. Joaquim Albareda and Manuel Herrero Sánchez (Eds.) "Constitution and Political Representation in the Crown of Aragon". In Political Representation in the Ancien Règime. New York, London: Routledge, pp. 145-160.

Orestano, R. 1987. Introduzione allo studio del diritto romano. Bologna: Il Mulino.

Peguera, Lluys de. 1701. Practica, forma, y estil, de celebrar Corts Generals en Cathalunya, y materiasincidents en aquelles. Barcelona.

Palomo, C. 2019. "Denominaciones históricas de la Corona de Aragón. Balance crítico e historiográfico". eHumanista/IVITRA 16: 160-180. https://www.ehumanista.ucsb.edu/sites/ default/files/sitefiles/ivitra/volume16/1.\%20Palomo.pdf

Pergiovani, V. 1994. "Il diritto canonico: il medioevo". In Gian Paolo Brizzi and Jacques Verger (Eds.) L'Università dell'Europa. Le scuole e i Maestri. Il Medioevo. Milano: Pizzi, pp. 211237. 
Ripoll Sastre, P. 2018. Llibre de vuit senyals (15th century): An edition, legal and comparative study.Doctoral dissertation, Universitat Pompeu Fabra.

Sánchez, M.1992. "La fiscalidad real en Cataluña (siglo XIV)". Anuario de estudios medievales, 22:341-376.

Sánchez Martínez, M. and Ortí Gost, P. 1997. "Introducció”. In Manuel Sánchez i Pere Ortí (Eds.). Corts, Parlaments i Fiscalitat a Catalunya: els capítols del donatiu (1288-1384). Barcelona: Textos Jurídics Catalans (Parlament de Catalunya i Departament de Justícia de la Generalitat de Catalunya).

Terradas Saborit, I. 2019. La justicia más antigua: teoría y cultura del ordenamiento vindicatorio. Madrid: CSIC.

Vicens Vives, J. 1954. Noticia de Cataluña. Barcelona: Àncora.

Vicens Vives, J. 2010. Notícia de Catalunya. Nosaltres els catalans [1960]. Barcelona: Vicens Vives.

Zeller, O. (ed.) 1966. Corppus iuris civilis iustinianei, studio et opera Ioannis Fehi, reimprssio phototypica editionis 1627. Osnabrück. 